\title{
Resolution of fatty liver disease after growth hormone replacement in a pediatric survivor of thyroid cancer
}

\author{
América L. Miranda-Lora ${ }^{1 *}$, Luis E. Zamora-Nava², Deyanira L. Marín-Rosas ${ }^{1}$, Miguel Klünder-Klünder ${ }^{3,4}$, \\ Mariana Sánchez-Curie/ ${ }^{5}$ and Pilar Dies-Suárez ${ }^{5}$ \\ ${ }^{1}$ Unidad de Investigación en Medicina Basada en Evidencias, Hospital Infantil de México Federico Gómez; ${ }^{2}$ Departamento de Endoscopia, Instituto \\ Nacional de Ciencias Médicas y Nutrición Salvador Zubirán; ${ }^{3}$ Subdirección de Gestión de la Investigación, Hospital Infantil de México Federico \\ Gómez; ${ }^{4}$ Research Committee, Latin American Society for Pediatric Gastroenterology, Hepatology and Nutrition (LASPGHAN); ${ }^{5}$ Departamento de \\ Radiología, Hospital Infantil de México Federico Gómez. Mexico City, Mexico
}

\begin{abstract}
Background: A rare case of primary papillary thyroid cancer (PTC) and growth hormone (GH) deficiency in a pediatric patient is described. In addition, the patient developed fatty liver disease attributed to GH deficiency. Case report: A 10-year-old male with a history of PTC with extension to the cervical nodes detected at 5 years of age was referred to the endocrinology consultation due to a low growth rate. On examination, GH deficiency was detected (height -3.51 standard deviations and low insulin-like growth factor-1 levels). This hormonal deficiency was not associated with thyroid cancer or treatment. Furthermore, elevated transaminases ( 300 IU/ml), lipids, and fally liver disease by ultrasound were detected. These data suggested fatty liver disease, which was attributed to GH deficiency. Regardless of the risk of recurrence, somatotropin was administered due to liver dysfunction and very short stature of the patient. A considerable improvement in growth, transaminases, and lipid profile was observed. At present, at 14 years of age, resolution of hepatic steatosis and a considerable increase in his growth rate without recurrence of thyroid cancer 9 years after its diagnosis and 4 years after the initiation of GH treatment are confirmed. Conclusions: GH therapy could be a good therapeutic option for pediatric cancer survivors to address impaired growth and fatty liver disease. However, additional medical evidence based on clinical trials is necessary to determine the benefits.
\end{abstract}

Key words: Fatty liver disease. Thyroid cancer. Growth hormone deficiency. Children.

\section{Resolución de enfermedad hepática grasa posterior al reemplazo con hormona de crecimiento en un paciente pediátrico sobreviviente a cáncer de tiroides}

\section{Resumen}

Introducción: Se presenta el caso de un paciente pediátrico con una asociación de cáncer papilar de tiroides (CPT) y deficiencia de hormona de crecimiento (HC) que no ha sido descrita previamente. Además, presenta enfermedad hepática grasa atribuida a la deficiencia hormonal. Caso clínico: Paciente de sexo masculino con antecedente de CPT con extensión a los ganglios cervicales diagnosticado a los 5 años de edad. Es referido a los 10 años por talla baja, sin datos de recurrencia del CPT. En el abordaje diagnóstico se detecta deficiencia de HC basándose en una estatura 3.51 desviaciones estándar por debajo de la media y niveles bajos de factor de crecimiento insulínico tipo 1. Adicionalmente, se detectó 
elevación de transaminasas ( 300 IU/ml), dislipidemia y esteatosis hepática en el ultrasonido. Después de los estudios de extensión, la enfermedad hepática grasa se atribuyó a la deficiencia de HC. A pesar del riesgo de recurrencia del cáncer de tiroides, se decidió dar tratamiento con HC debido a la afectación hepática y de crecimiento. El paciente presentó una evolución satisfactoria y actualmente, a la edad de 14 años, la esteatosis hepática está resuelta, presenta una mejoría considerable en su estatura y no ha tenido recurrencia del cáncer de tiroides 9 años después del diagnóstico y 4 años después del inicio del tratamiento con HC. Conclusiones: El tratamiento con HC puede ser una adecuada opción terapéutica para sobrevivientes de cáncer en la edad pediátrica con afectación en el crecimiento y esteatosis hepática. Sin embargo, se requieren estudios con mayor evidencia científica y seguimiento a largo plazo para apoyar esta afirmación.

Palabras clave: Enfermedad hepática grasa. Cáncer de tiroides. Deficiencia de crecimiento. Niños.

\section{Introduction}

Pediatric thyroid carcinoma remains as a rare diagnosis despite approximately $1 \%$ annual rate increase. Overall, pediatric thyroid carcinoma demonstrates an excellent prognosis when identified early and treated adequately. Thyroid resection combined with the selective use of radioactive iodine (RAI) ablation is a safe and effective treatment for recurrent papillary thyroid cancer (PTC) in children. However, lymph node extension is a risk factor for recurrence $(26-47 \%)^{1,2}$.

Growth hormone deficiency (GHD) is the main endocrinopathy in pediatric cancer survivors ${ }^{3,4}$. This disorder is observed in some types of pediatric cancer, such as acute lymphoblastic leukemia and brain tumors, and it is mainly attributable to the disease (type or location of tumor) or its treatment (surgery and radiotherapy) ${ }^{3}$. To the extent of our knowledge, the association between GHD and primary PTC or its treatment has not been yet reported.

$\mathrm{GH}$ and insulin-like growth factor-1 (IGF-1) affect tumor growth in vitro and some animal models ${ }^{5}$. Some studies have examined the relationship between $\mathrm{GH}$ treatment and cancer risk, but the current evidence is inconclusive ${ }^{3,5,6}$. In contrast, evidence exists regarding the benefits of $\mathrm{GH}$ treatment in childhood cancer survivors with $\mathrm{GHD}^{4,7,8}$.

Non-alcoholic fatty liver disease (NAFLD) is the most common cause of chronic liver disease in children ${ }^{9}$. NAFLD has been associated with hypothyroidism, adrenal insufficiency, hypogonadotropic hypogonadism, and $\mathrm{GHD}^{10}$. Furthermore, cases of NAFLD associated with GHD with a satisfactory response to $\mathrm{GH}$ treatment have been reported ${ }^{7,11,12}$. However, no cases of NAFLD have been reported in patients with GHD with a history of primary PTC.

\section{Case report}

A 10-year-old male patient was referred to the endocrinology consultation due to short stature. He was born at full term by elective cesarean section after an uncomplicated first gestation with a birth weight of $2950 \mathrm{~kg}$, height $49 \mathrm{~cm}$, and Apgar 7/9. No history of blood transfusion or drug abuse was reported. He has normal neurocognitive development and good school performance. His mother informed history of Hashimoto's thyroiditis and a thyroid nodule resolved with hemithyroidectomy. Furthermore, a history of thyroid cancer in his maternal grandmother was reported.

At the age of 5 years, a thyroid nodule was detected, and the biopsy indicated PTC with extension to the cervical nodes. He was treated with total thyroidectomy and required two doses of RAl ablation with $100 \mathrm{mCi}$ due to the presence of functional thyroid tissue in the gland bed. The patient received levothyroxine $62.5 \mu \mathrm{g} /$ day, which provided an adequate substitution.

The patient presented after 18 months of no follow-up for a growth evaluation. His mother reported low growth rate since he was 3 years old (before the diagnosis of thyroid cancer), for which the patient was worried. On physical examination, the patient appeared younger than his chronological age: height $116.5 \mathrm{~cm}(-3.51$ standard deviation [SD]), weight $26 \mathrm{~kg}(-1.67 \mathrm{SD})$, and body mass index $=19.2 \mathrm{~kg} / \mathrm{m}^{2}(+1.18 \mathrm{SD})$ according to child growth standards ${ }^{13}$ (Fig. 1). No acanthosis or thyroid or cervical lymph nodes were detected. A large, firm liver was palpable, although his spleen was not palpable. His sexual development was in Tanner 1 stage.

Laboratory data revealed the following results: aspartate aminotransferase $=165 \mathrm{IU} / \mathrm{l}$, alanine aminotransferase $=133 \mathrm{IU} / \mathrm{l}$, gamma-glutamyl transpeptidase = $92 \mathrm{IU} / \mathrm{l}$, lactic dehydrogenase $=318 \mathrm{mg} / \mathrm{dl}$, alkaline phosphatase $=193 \mathrm{IU} / \mathrm{l}$, total bilirubin $=0.57 \mathrm{mg} / \mathrm{dl}$, direct bilirubin $=0.09 \mathrm{mg} / \mathrm{dl}$, indirect bilirubin = $0.48 \mathrm{mg} / \mathrm{dl}$, total cholesterol $=262 \mathrm{mg} / \mathrm{dl}$, high-density lipoprotein cholesterol $=34.9 \mathrm{mg} / \mathrm{dl}$, low-density lipoprotein cholesterol $=179.5 \mathrm{mg} / \mathrm{dl}$, triglycerides $=238 \mathrm{mg} /$ dl, white blood cell count $=4300 / \mu \mathrm{l}$, hemoglobin $=$ $12.8 \mathrm{~g} / \mathrm{dl}$, fasting glucose $=64 \mathrm{mg} / \mathrm{dl}$, fasting insulin = 


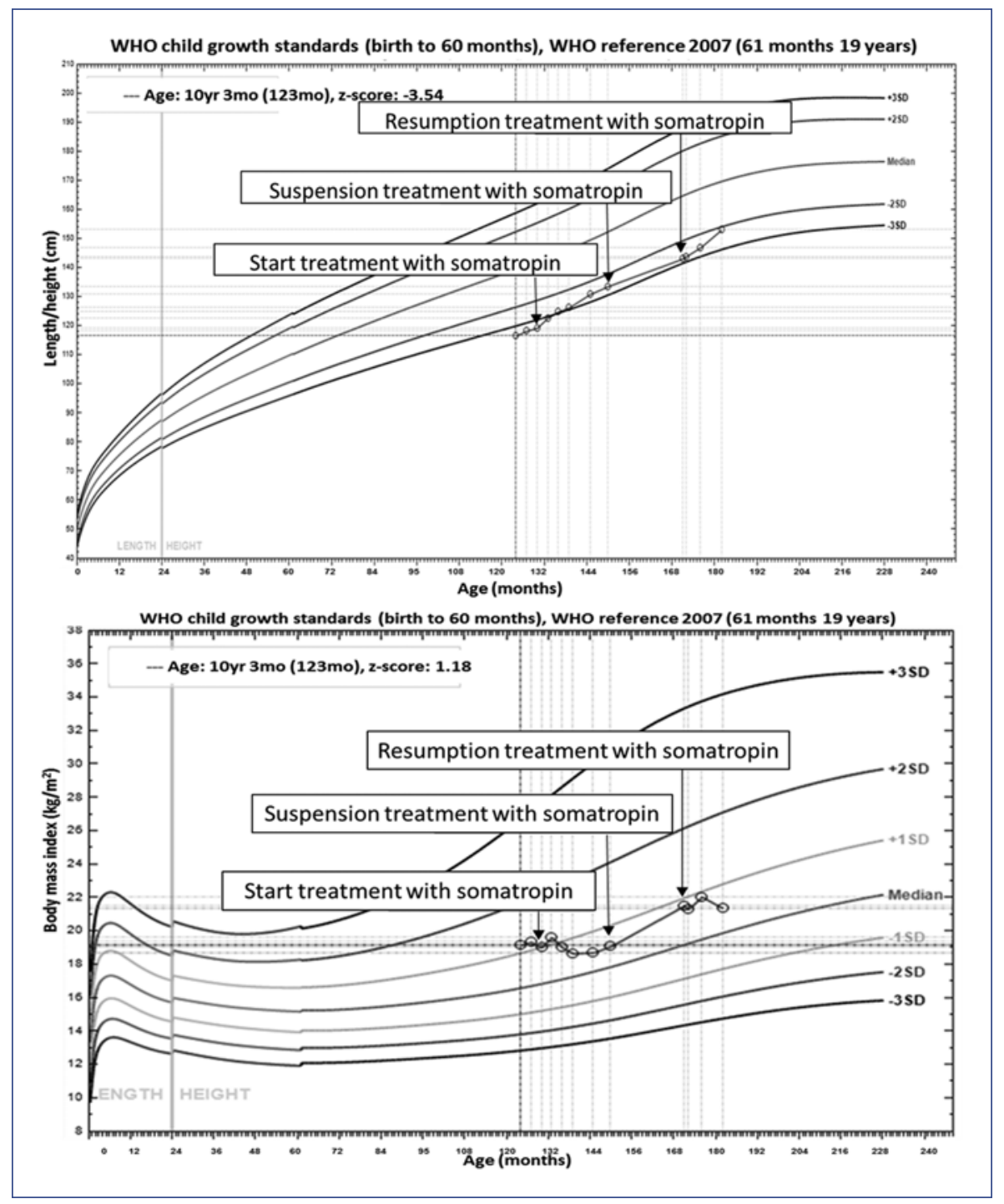

Figure 1. Growth charts at follow-up.

$2.3 \mathrm{mlU} / \mathrm{ml}$, and homeostatic model assessment for insulin resistance $(\mathrm{IR})=0.36$. The results of serological testing for antibodies to antinuclear, antimitochondrial, anti-LKM (antiliver kidney microsome antibodies) and viral hepatitis (hepatitis A antibody, hepatitis B surface antigen, hepatitis B surface antibody, hepatitis B core antibody, hepatitis $C$ virus antibody, and hepatitis $C$ virus-RNA) were all negative. His bone age was evaluated as 8.5 years using the Greulich-Pyle atlas for a chronological age of 10 years. Other laboratory results included thyroid-stimulating hormone $(\mathrm{TSH})=0.86 \mathrm{mIU} / \mathrm{l}$ (normal range 0.8-6.9), triiodothyronine $=1.44 \mathrm{ng} / \mathrm{ml}$ (normal range $0.8-2.1$ ), thyroxine $=7.98 \mu \mathrm{g} / \mathrm{dl}$ (normal range 5.5-12.8), free thyroxine $=0.95 \mathrm{ng} / \mathrm{dl}$ (normal range $0.65-1.9$ ), thyroglobulin $=7.71 \mathrm{ng} / \mathrm{ml}$ (normal range 12-113), antithyroglobulin $=5.3 \mathrm{IU} / \mathrm{ml}$ (normal range $<1.0)$, IGF-1 $=65.4 \mathrm{ng} / \mathrm{ml}(-2.66 \mathrm{SD})$, adrenocorticotropic hormone $=35.2 \mathrm{pg} / \mathrm{ml}$ (normal range 6-48), morning cortisol $=23.91 \mu \mathrm{g} / \mathrm{dl}$ (normal range 3-25), and 25-hydroxyvitamin $D=7.8 \mathrm{ng} / \mathrm{ml}$ (normal range 30-100).

Hepatic ultrasound revealed hepatomegaly with fat deposition suggestive of moderate hepatic steatosis (Fig. 2) without splenomegaly. The family did not agree to perform a liver biopsy. No abnormal brain findings were shown by magnetic resonance imaging (Fig. 3). Thyroid gammagram with ${ }^{131}$ I and thyrotropin alpha stimulation (TSH $=43.26 \mathrm{mIU} / \mathrm{l}$ ) was considered within the normal limits, and no data suggested residual thyroid tissue.

The treatment with levothyroxine at a dose of $62.5 \mu \mathrm{g} /$ day, supplementation with Vitamin $D$ and 


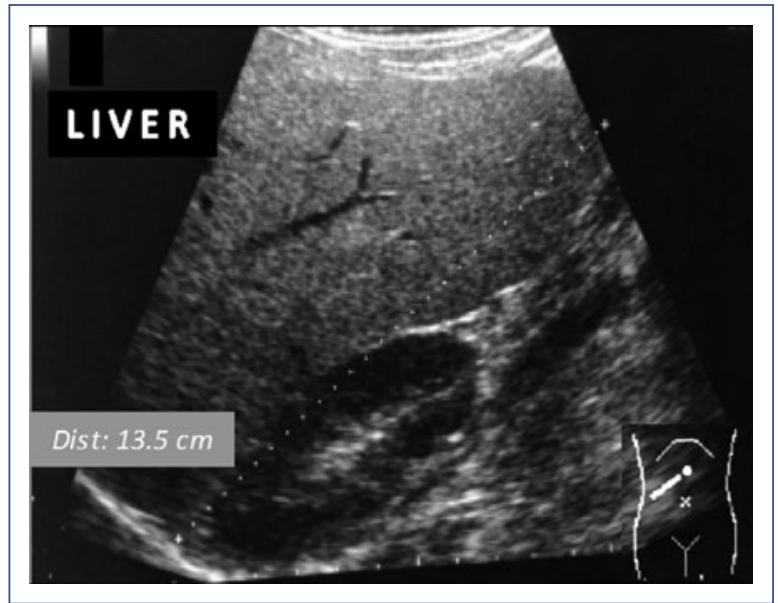

Figure 2. Hepatic ultrasound. The echogenicity of the liver was higher than that of the renal cortex, with intrahepatic vessels not well depicted.

nutritional support continued. No significant improvement in growth was observed (Fig. 1), and transaminases continued to increase (Fig. 4). Due to liver alterations, lower IGF-1 levels in a second sample $(30 \mathrm{ng} / \mathrm{ml}$; -3.93 SDS), very short stature and the fact that the last screening did not show residual thyroid tissue, the mother and the patient were strongly advised to decide for $\mathrm{GH}$ treatment. The risks of the treatment were explained, mainly those related to the history of TPC with cervical node extension. The treatment started with somatotropin at a dose of $0.25 \mathrm{mg} / \mathrm{kg} /$ week and continued with levothyroxine.

After 17 months of somatotropin treatment, the patient reported more energy, improved self-esteem, and better general conditions. Furthermore, hepatomegaly reduction with a marked decrease of transaminases was observed (Fig. 4A), as well as an improved lipid profile (Fig. 4B) and a significant growth improvement (Fig. 1). The patient could not afford the somatotropin treatment any longer for which he spent 21 months without medical supervision. However, he continued the levothyroxine treatment, nutritional support, and physical activity.

Later, he turned to the service reporting fatigue and a low growth velocity rate (Fig. 2). Laboratory tests showed abnormal liver function and lipid profile (Fig. 4). Due to the evolution of the patient, treatment with somatotropin was resumed.

IGF-1 levels were found within the normal range during the treatment with $\mathrm{GH}(152 \mathrm{ng} / \mathrm{ml},-1.3 \mathrm{SDS}$ at age 12 and $210.7 \mathrm{ng} / \mathrm{ml},-0.49$ SDS at age 13). At present, the patient reports good general condition: growth

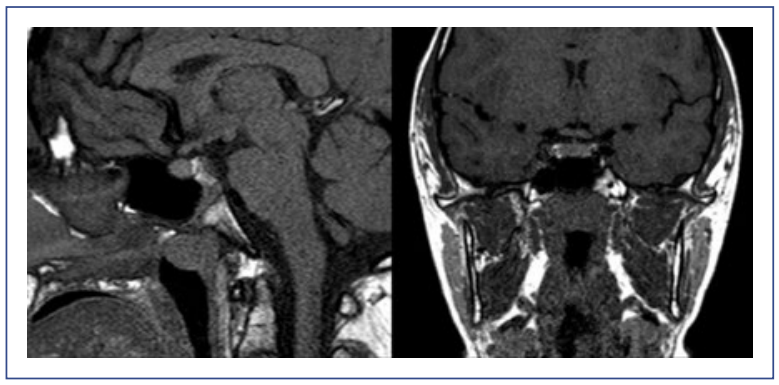

Figure 3. Magnetic resonance imaging in the pituitary region topography with no evidence of lesions occupying the space and glands with normal signal intensity.

rate is recovering, the puberty started (Tanner 2), and transaminases and lipid profile have reached normal values (Fig. 4) with the resolution of hepatic steatosis on ultrasound (Fig. 5). At present, at 14 years of age, no recurrence of thyroid cancer has appeared 9 years after diagnosis and 4 years after the start of GH therapy. The last thyroid gammagram with ${ }^{131}$ I was considered within the standard limits and no data suggestive of residual thyroid tissue and undetectable TSH-stimulated thyroglobulin (with negative $\mathrm{Ab}$ antithyroglobulin). At present, the patient continues with levothyroxine treatment, Vitamin D and $\mathrm{GH}$ and undergoes routine examinations for cancer follow-up and hormonal replacement.

\section{Discussion}

To the extent of our knowledge, this is the first case report describing a pediatric survivor of primary PTC with GHD that contributed to the development of fatty liver disease, which improved after $\mathrm{GH}$ replacement therapy. There was no cancer recurrence for 4 years of follow-up.

Auxological criteria and the low levels of IGF-1 (-2.66 SDS at age 10 and -3.93 SDS at age 11) support the diagnosis of GHD in this patient. However, the lack of GH generation tests would be a limitation for the diagnostic approach in this case. Due to the pulsatile $\mathrm{GH}$ secretion and minimum GH concentration between pulses, the random serum GH concentration is of no clinical utility. Instead, GH provocation tests are considered the basis of GHD diagnosis, as no true gold standard exists $^{14-17}$. IGF-1 has been suggested to have a high specificity but relatively poor sensitivity for GHD diagnosis ${ }^{15,18}$. Guzzetti et al. reported a cutoff point of -0.5 SDS for sensitivity at $95 \%$ and -2.9 SDS for specificity at $95 \%{ }^{19}$, which means that a standard value of IGF-1 


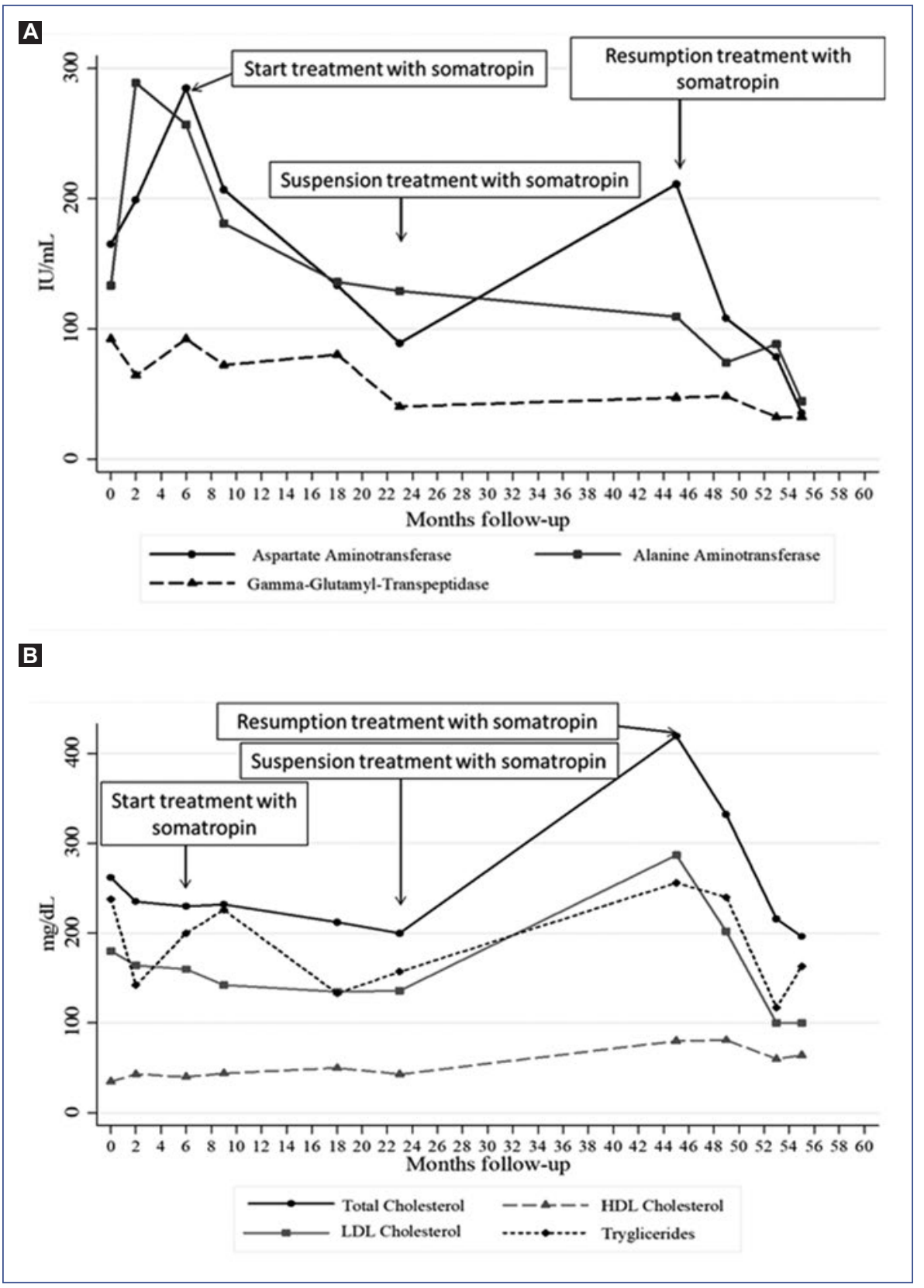

Figure 4. Transaminase (A) and lipid profile (B) curve.

does not exclude GHD, but the lowest levels, as in this patient, are highly predictive of GHD. Patients with GH resistance or primary IGF-1 deficiency also show the smallest values of IGF-1. In these cases, the response with $\mathrm{GH}$ is not satisfactory ${ }^{20}$, which contrasts with the response of the patient of the present report.

Late-onset endocrine abnormalities in survivors of childhood cancer can include GHD and other hormone defects $^{3}$. The main clinical presentation in pediatric patients with GHD is short stature. However, the low growth rate can be induced by other conditions such as reduced nutritional intake, steroid administration, psychological dysfunction, and other abnormalities of the hypothalamic-pituitary glands (e.g., hypothyroidism and hypogonadism $)^{4}$ that were excluded in this patient.

GHD is a consequence of hypothalamic-pituitaryadrenal axis damage in pediatric cancer survivors due to a brain tumor, central nervous system surgery, or cranial radiotherapy ${ }^{21}$. However, PTC or RAl ablation 


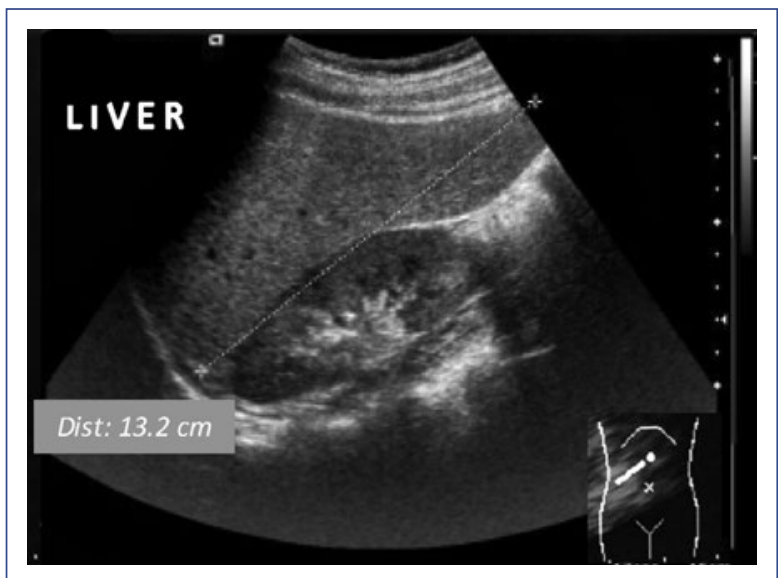

Figure 5. Hepatic ultrasound at present (age 14). The echogenicity of the liver is equal to that of the renal cortex.

treatment has not been associated with GHD. For that reason, no reports of thyroid cancer survivors treated with $\mathrm{GH}$ were found in literature. In this patient, GHD was considered as an independent entity that was not due to PTC. GHD might have started before the cancer diagnosis given that the patient showed a low growth rate since he was a toddler. However, further genetic analysis is required to find an explanation regarding the etiology of GHD.

$\mathrm{GH}$ replacement has been demonstrated to be an effective treatment for reducing growth impairment in survivors of childhood cancer with $\mathrm{GHD}^{8}$. Although there is some evidence that GH therapy does not increase the risk of malignancy, some authors have reported that a risk could exist, especially in terms of the development of subsequent neoplasms, and most authors cite the need for more additional evidence $e^{3,6,22,23}$.

Thyroid cancer has been reported as a secondary neoplasm, with a relative risk of 2.15-3.21 among $\mathrm{GH}$-treated survivors ${ }^{23,24}$. Despite the development of secondary thyroid neoplasms in cancer survivors treated with $\mathrm{GH}$, it cannot be concluded that $\mathrm{GH}$ induces carcinogenesis. It is well-known that radiation can induce long-term thyroid damage, including thyroid cancer, and over $90 \%$ of these patients have also received skull radiotherapy ${ }^{25}$.

Somatotropin can be used to treat GHD in childhood cancer survivors who are in remission, with the understanding that $\mathrm{GH}$ therapy might increase the risk of secondary neoplasms ${ }^{4,6,23}$. However, assessing recurrence or second malignancies during long-term follow-up is crucial ${ }^{24}$. Although pediatric thyroid carcinomas have an excellent prognosis if identified timely and managed adequately, children show a higher recurrence rate than adults $(\sim 47 \%$ for papillary thyroid carcinoma) $)^{2,26}$.

GHD is associated with multiple features of the metabolic syndrome, including IR, obesity, dyslipidemia, hypertension, and NAFLD ${ }^{12,27}$. Interestingly, the present case only developed hepatic fatty liver disease and never showed signs of overweight, obesity, or IR. On the one hand, these features could be related to another pathway of hepatic steatosis independent from obesity/IR. On the other hand, the development of these characteristics might be a question of time, as demonstrated in a retrospective study of patients with hypothalamic and pituitary dysfunction in which fasting blood glucose levels were elevated in approximately $5 \%$ of patients at the time of diagnosis and in $62 \%$ of patients later. However, in a retrospective study of adult hypopituitary patients with GHD, the prevalence of NAFLD was significantly increased independently of obesity ${ }^{28}$.

NAFLD is a complex clinical-pathological entity defined as an excessive accumulation of fat in the liver in the form of triglycerides, called steatosis (histological infiltration $>5 \%$ of hepatocytes) $)^{9,29}$. Unfortunately, the level of infiltration could not be confirmed with a biopsy in this case. NAFLD has been associated with an increased risk of all-cause and cancer-specific mortality among cancer survivors ${ }^{29}$. Although hypothyroidism appears to be an independent risk factor for NAFLD/ NASH (non-alcoholic steatohepatitis), this patient always maintained adequate hormone replacement therapy. Growing evidence suggests that GHD and low IGF-1 levels may play significant roles in the development and progression of NAFLD, including steatohepatitis as an independent risk factor ${ }^{10,27,28}$.

Previously, other authors have reported NAFLD improvement with $\mathrm{GH}$ treatment in some cases ${ }^{7,10,11,30}$. A patient with GHD related to NAFLD who required liver transplantation and was treated successfully with $\mathrm{GH}$ replacement was reported ${ }^{11}$. Although no substantial evidence regarding the efficacy of GH for NAFLD in GHD (lack of clinical trials) was demonstrated in this patient, liver damage improved with the $\mathrm{GH}$ replacement therapy, and transaminases increased when the $\mathrm{GH}$ replacement therapy was suspended. Given the lack of effective diagnostic and treatment options currently available for children, this area certainly deserves further investigation ${ }^{31}$.

Therapy with GH or IGF-1 improves the degree of liver steatosis and fibrosis, upgrades mitochondrial function, and reduces oxidative stress, which results 
in histologic improvement in NAFLD ${ }^{32}$. There are some explanations for the mechanisms by which the GH/IGF-1 axis contributes to this improvement. Some studies in human and animal models have proposed that $\mathrm{GH} / \mathrm{IGF}-1$ regulates the expression of numerous genes such as Mup1 (major urinary protein 1), Selenbp2 (selenium-binding protein 2), Ccnd1 (cyclin D1), Socs2 (suppressor of cytokine signaling 2), Socs3 (suppressor of cytokine signaling 3), epidermal growth factor receptor (EGFR), IGF-1, NNMT (nicotinamide N-methyltransferase), IGFLS (insulin growth factor-like), P4AH1 (collagen proly 4 hydroxylase 1), SLC16A1 (solute carrier family 16 member 1), SRD5A1 (steroid 5 alpha-reductase 1), FADS1 (fatty acid desaturase 1), and AKR1B10 (aldo-keto reductase family 1 member B10). Furthermore, other serum markers of inflammation, such as TNF $\alpha$ (tumor necrosis factor alpha), TGF $\beta$ (transforming growth factor beta), CCL3, and fibrotic markers such as Col1A2 (collagen type I alpha 2 chain) and Col3A1 (collagen type III alpha 1 chain) as well, which are involved in glucose and lipid metabolism ${ }^{32-37}$. In addition, the GH pathway has shown to play a significant role in liver regeneration through the control of EGFR activation. GH/ EGFR pathway downregulation is a general mechanism responsible for liver regeneration deficiency associated with steatosis ${ }^{38}$.

GH treatment could benefit growth and metabolism in cancer childhood survivors $3,6,22,23$. In the present case, the decision to start GH was controversial. Despite the theoretical risk of cancer recurrence, it was decided to begin the treatment in this patient to improve his growth rate, but mainly to limit the damage to the liver. Although therapy with $\mathrm{GH}$ can be safe, a close long-term follow-up is necessary for childhood cancer survivors. Concerns about the potential to increase the risk of developing cancer (de novo, recurrence, or secondary neoplasms) continue. Both his family and the medical team recognized the potential risks of $\mathrm{GH}$ treatment, for which is necessary to persist with longterm surveillance of GH therapy and the current recommendations for the follow-up of PTC in children ${ }^{1,2,24}$.

The patient should be reevaluated for GHD on completion of growth with a pharmacological stimulus (e.g., insulin, glucagon, and ghrelin) ${ }^{16,39}$. If GHD diagnosis is confirmed, GH replacement therapy in adulthood will continue to be controversial. On the one hand, the theoretical risk of recurrence of cancer with $\mathrm{GH}$ and, on the other hand, the deleterious effects on bone mineral density, lipid profile and liver function tests without $\mathrm{GH}$ treatment ${ }^{40}$.
As an overall conclusion, GH therapy could be a good therapeutic option for pediatric cancer survivors to address impaired growth and fatty liver disease. However, additional medical evidence based on clinical trials is necessary to evaluate benefits versus risks. Surveillance is essential for all individuals who are treated with $\mathrm{GH}$, particularly those with an underlying predisposition for developing cancer.

\section{Ethical disclosures}

Protection of human and animal subjects. The authors declare that no experiments were performed on humans or animals for this study.

Confidentiality of data. The authors declare that they have followed the protocols of their work center on the publication of patient data.

Right to privacy and informed consent. The authors have obtained the written informed consent of the patients or subjects mentioned in the article. The corresponding author is in possession of this document.

\section{Conflicts of interest}

The authors declare that they have no conflicts of interest.

\section{Funding}

There was no external source of funding related to this research.

\section{References}

1. Francis GL, Waguespack SG, Bauer AJ, Angelos $P$, Benvenga $S$, Cerutti JM, et al. Management guidelines for children with thyroid nodules and differentiated thyroid cancer. Thyroid. 2015;25:716-59.

2. Verburg FA, Van Santen HM, Luster M. Pediatric papillary thyroid cancer: current management challenges. Onco Targets Ther. 2017;10:165-75.

3. Ergun-Longmire B, Mertens AC, Mitby P, Qin J, Heller G, Shi W, et al. Growth hormone treatment and risk of second neoplasms in the childhood cancer survivor. J Clin Endocrinol Metab. 2006;91:3494-8.

4. Felicetti F, Fortunati N, Arvat E, Brignardello E. GH deficiency in adult survivors of childhood cancer. Best Pract Res Clin Endocrinol Metab. 2016;30:795-804.

5. Renehan AG, Zwahlen M, Minder C, O'Dwyer ST, Shalet SM, Egger M. Insulin-like growth factor (IGF)-1, IGF binding protein-3, and cancer risk: systematic review and meta-regression analysis. Lancet. 2004;363:1346-53.

6. Raman S, Grimberg A, Waguespack SG, Miller BS, Sklar CA, Meacham LR, et al. Risk of neoplasia in pediatric patients receiving growth hormone therapy-a report from the Pediatric Endocrine Society Drug and Therapeutics Committee. J Clin Endocrinol Metab. 2015;100:2192-203.

7. Takano S, Kanzaki S, Sato M, Kubo T, Seino Y. Effect of growth hormone on fatty liver in panhypopituitarism. Arch Dis Child. 1997;76:537-8.

8. Gleeson HK, Stoeter R, Ogilvy-Stuart AL, Gattamaneni HR, Brennan BM, Shalet SM. Improvements in final height over 25 years in growth hormone (GH)-deficient childhood survivors of brain tumors receiving $\mathrm{GH}$ replacement. J Clin Endocrinol Metab. 2003;88:3682-9.

9. Giorgio V, Prono F, Graziano F, Nobili V. Pediatric nonalcoholic fatty liver disease: old and new concepts on development, progression, metabolic insight and potential treatment targets. BMC Pediatr. 2013;13:40. 
10. Adams LA, Feldstein A, Lindor KD, Angulo P. Nonalcoholic fatty liver disease among patients with hypothalamic and pituitary dysfunction. Hepatology. 2004;39:909-14.

11. Gilliland T, Dufour S, Shulman GI, Petersen KF, Emre SH. Resolution of non-alcoholic steatohepatitis after growth hormone replacement in a pediatric liver transplant patient with panhypopituitarism. Pediatr Transplantat. 2016;20:1157-63.

12. Gardner CJ, Irwin AJ, Daousi C, McFarlane IA, Joseph F, Bell JD, et al Hepatic steatosis, GH deficiency and the effects of GH replacement: a Liverpool magnetic resonance spectroscopy study. Eur $\mathrm{J}$ Endocrinol. 2012;166:993-1002.

13. World Health Organization. The WHO Child Growth Standards. Geneva World Health Organization; 2017. Available at: https://www.who.int/childgrowth/standards/

14. Alatzoglou KS, Webb EA, Le Tissier P, Dattani MT. Isolated growth hormone deficiency (GHD) in childhood and adolescence: recent advances. Endocr Rev. 2014;35:376-432.

15. Cianfarani S, Tondinelli T, Spadoni GL, Scire G, Boemi S, Boscherini B. Height velocity and IGF-I assessment in the diagnosis of childhood onse $\mathrm{GH}$ insufficiency: do we still need a second GH stimulation test? Clin Endocrinol (Oxf). 2002;57:161-7.

16. Chinoy A, Murray PG. Diagnosis of growth hormone deficiency in the paediatric and transitional age. Best Pract Res Clin Endocrinol Metab. 2016;30:737-47

17. Grimberg A, Allen DB. Growth hormone treatment for growth hormone deficiency and idiopathic short stature: new guidelines shaped by the presence and absence of evidence. Curr Opin Pediatr. 2017;29:466-71.

18. Bidlingmaier M, Friedrich N, Emeny RT, Spranger J, Wolthers OD Roswall J, et al. Reference intervals for insulin-like growth factor-1 (igf-i) from birth to senescence: results from a multicenter study using a new automated chemiluminescence IGF-I immunoassay conforming to recent international recommendations. J Clin Endocrinol Metab. 2014:99:1712-21.

19. Guzzetti C, Ibba A, Pilia S, Beltrami N, Di lorgi N, Rollo A, et al. Cut-off limits of the peak $\mathrm{GH}$ response to stimulation tests for the diagnosis of GH deficiency in children and adolescents: study in patients with organic GHD. Eur J Endocrinol. 2016;175:41-7.

20. Grimberg A, DiVall SA, Polychronakos C, Allen DB, Cohen LE Quintos JB, et al. Guidelines for growth hormone and insulin-like growth factor-I treatment in children and adolescents: growth hormone deficiency, idiopathic short stature, and primary insulin-like growth factor-I deficiency. Horm Res Paediatr. 2016;86:361-97.

21. Swerdlow AJ, Reddingius RE, Higgins CD, Spoudeas HA, Phipps K Qiao Z, et al. Growth hormone treatment of children with brain tumors and risk of tumor recurrence. J Clin Endocrinol Metab. 2000;85:4444-9.

22. Chae HW, Kim DH, Kim HS. Growth hormone treatment and risk of malignancy. Korean J Pediatr. 2015;58:41-6.

23. Brignardello $E$, Felicetti $F$, Castiglione A, Fortunati $N$, Matarazzo $P$, Biasin E, et al. GH replacement therapy and second neoplasms in adult survivors of childhood cancer: a retrospective study from a single institution. J Endocrinol Invest. 2015;38:171-6.

24. Rosenfeld RG, Cohen P, Robison LL, Bercu BB, Clayton P, Hoffman AR et al. Long-term surveillance of growth hormone therapy. J Clin Endocrinol Metab. 2012:97:68-72.

25. Albi E, Cataldi S, Lazzarini A, Codini M, Beccari T, Ambesi-Impiombato FS, et al. Radiation and thyroid cancer. Int J Mol Sci. 2017;18.
26. La Quaglia MP, Corbally MT, Heller G, Exelby PR, Brennan MF. Recurrence and morbidity in differentiated thyroid carcinoma in children. Surgery. 1988; 104:1149-56.

27. Dichtel LE, Corey KE, Misdraji J, Miriam A Bredella, Melanie Schorr, Stephanie A Osganian, et al. The association between IGF-1 levels and the histologic severity of nonalcoholic fatty liver disease. Clin Transl Gastroenterol. 2017;8:e217.

28. Nishizawa $H$, Iguchi $G$, Murawaki $A$, Fukuoka $H$, Hayashi $Y, K a j i ~ H$, et al. Nonalcoholic fatty liver disease in adult hypopituitary patients with $\mathrm{GH}$ deficiency and the impact of GH replacement therapy. Eur J Endocrinol. 2012;167:67-74

29. Brown JC, Harhay MO, Harhay MN. Nonalcoholic fatty liver disease and mortality among cancer survivors. Cancer Epidemiol. 2017;48:104-9.

30. Takahashi Y, lida K, Takahashi K, Yoshioka S, Fukuoka H, Takeno R, et al. Growth hormone reverses nonalcoholic steatohepatitis in a patient with adult growth hormone deficiency. Gastroenterology. 2007;132:938-43.

31. Chishima S, Kogiso T, Matsushita N, Hashimoto E, Tokushige K. The relationship between the growth hormone/insulin-like growth factor system and the histological features of nonalcoholic fatty liver disease. Intern Med. 2017;56:473-80.

32. Sumida Y, Yonei Y, Tanaka S, Mori K, Kanemasa K, Imai S, et al. Lower levels of insulin-like growth factor-1 standard deviation score are associated with histological severity of non-alcoholic fatty liver disease. Hepatol Res. 2015;45:771-81.

33. De Ita JR, Castilla-Cortazar I, Aguirre GA Sánchez-Yago C Santos-Ruiz $\mathrm{MO}$, Guerra-Menéndez L, et al. Altered liver expression of genes involved in lipid and glucose metabolism in mice with partial IGF-1 deficiency: an experimental approach to metabolic syndrome. J Transl Med. 2015;13:326.

34. Fan Y, Fang X, Tajima A, Geng X, Ranganathan S, Dong H, et al. Evolution of hepatic steatosis to fibrosis and adenoma formation in liver-specific growth hormone receptor knockout mice. Front Endocrinol (Laussane). 2014:5:218

35. Tateno C, Kataoka M, Utoh R, Tachibana A, Itamoto T, Asahara T, et al. Growth hormone-dependent pathogenesis of human hepatic steatosis in a novel mouse model bearing a human hepatocyte-repopulated liver. Endocrinology. 2011;152:1479-91.

36. Nishizawa H, Takahashi M, Fukuoka H, Iguchi G, Kitazawa R, Takahashi Y. GH-independent IGF-I action is essential to prevent the development of nonalcoholic steatohepatitis in a GH-deficient rat model. Biochem Biophys Res Commun. 2012;423:295-300.

37. Qin Y, Tian YP. Exploring the molecular mechanisms underlying the potentiation of exogenous growth hormone on alcohol-induced fatty liver diseases in mice. J Transl Med. 2010;8:120.

38. Collin de l'Hortet A, Zerrad-Saadi A, Prip-Buus C, Fauveau V, Helmy N, Ziol M, et al. GH administration rescues fatty liver regeneration impairment by restoring GH/EGFR pathway deficiency. Endocrinology. 2014;155:2545-54

39. Yuen KC, Tritos NA, Samson SL, Hoffman AR, Katznelson L. American Association of Clinical Endocrinologists and American College of Endocrinology Disease State clinical review: update on growth hormone stimulation testing and proposed revised cut-point for the glucagon stimulation test in the diagnosis of adult growth hormone deficiency. Endocr Pract. 2016;22:1235-44.

40. Loche S, Di lorgi N, Patti G, Noli S, Giaccardi M, Olivieri I, et al. Growth hormone deficiency in the transition age. Endocr Dev. 2018;33:46-56. 